\title{
Human-related factors regulate the presence of domestic dogs in protected areas
}

\author{
Carolina A. Soto and Francisco Palomares
}

\begin{abstract}
The presence of domestic species such as dogs Canis familiaris in protected areas can cause problems for native species as a result of competition, predation and disease transmission. To improve our ability to design effective control policies we investigated the factors affecting detection of dog tracks in a Mediterranean national park.

We investigated the presence of dogs across $692 \times 2 \mathrm{~km}$ grid squares in Doñana National Park in south-west Spain and used logistic regression models to analyse the associated environmental and human constraints. We did not detect dogs in areas away from the edges of the national park close to human settlements (track census effort $>470 \mathrm{~km}$ ) and the detection of dog tracks was correlated with human presence. We conclude that domestic dogs occasionally enter the Park from the surrounding area and are a direct threat to wildlife at the edges of the Park. Management actions to reduce the effects of domestic dogs in protected areas where feral dog populations are not established should focus on the spatial extent of local settlements, regulation and awareness-raising to encourage responsible dog-ownership, and control measures such as removing un-owned dogs from boundaries and areas close to human dwellings, and forbidding unleashed dogs in public facilities.
\end{abstract}

Keywords Anthropogenic effect, Canis familiaris, domestic dog, edge effect, feral dog, generalist predator, human dwelling

\section{Introduction}

Uting rbanization of natural landscapes brings humans and their companion animals into contact with wildlife (Ordeñana et al., 2010), and they sometimes encroach on protected areas. Domestic dogs Canis familiaris pose distinct threats to wildlife. They harass wildlife and exhibit a surplus-killing behaviour (Kruuk \& Snell, 1981; Manor \& Saltz, 2004; Banks \& Bryant, 2007), compete for resources (Butler \& du Toit, 2002; Butler et al., 2004; Vanak et al., 2009) and spread diseases such as rabies, parvovirus and canine distemper (Cleaveland et al., 2000; Fiorello et al., 2006; Vanak \& Gompper, 2009a). Dogs can also exert a top-

Carolina A. Soto (Corresponding author) and Francisco Palomares Department of Conservation Biology, Estación Biológica de Doñana, CSIC, Sevilla, Spain. E-mail sotonavarrocarolina@gmail.com

Received 26 October 2012. Revision requested 25 February 2013. Accepted 22 March 2013. First published online 13 October 2014. down influence on smaller carnivores through interference competition or intraguild predation (Glen \& Dickman, 2005; Mitchell \& Banks, 2005; Vanak \& Gompper, 2009b).

The effects of dogs on wildlife depend on their nature (domestic vs feral), on where they are found and on the factors controlling their numbers and use of space.

Domestic dogs are found in higher densities in areas with high human population density (Odell \& Knight, 2001; Ordeñana et al., 2010) and in rural areas where agricultural land borders nature reserves. The presence of domestic dogs in protected areas and their direct negative effects on native fauna are most significant at the borders, showing a decreasing trend from the anthropogenic matrix to the interior of the protected area (Torres \& Prado, 2010). Dogs could therefore exacerbate the negative anthropogenic edge effect associated with such border areas (Woodroffe \& Ginsberg, 1998; Revilla et al., 2001).

Feral dogs are completely wild and independent of humans (Nesbitt, 1975; Green \& Gipson, 1994), depending almost exclusively on wild-caught food (Glen \& Dickman, 2005; Mitchell \& Banks, 2005). The direct threats of feral dogs to wildlife may therefore occur throughout entire protected areas.

In this context we studied the patterns of detection of dog tracks and the associated environmental and human constraints that could influence their presence in Doñana National Park, Spain, which has a high potential for the arrival and settlement of dogs, given its size and proximity to human settlements. We addressed two research questions: (1) Are dogs present in the Park? (2) What factors predict dog presence? We hypothesized that dogs using the Park could be either domestic dogs that enter occasionally from the surrounding matrix and are more abundant at the edges of the Park close to human settlements, or feral dogs that live and reproduce freely and are more evenly distributed throughout the Park, depending on habitat suitability and the availability of food. Doñana National Park is optimal for a study of this type because only part of its border is contiguous with human settlements and it is sufficiently large to potentially hold a feral dog population in its interior.

\section{Study area}

Doñana National Park is a flat sandy area located in southwest Spain (Fig. 1). We defined the anthropogenic edges of the Park as the northern and western edges, which are in 


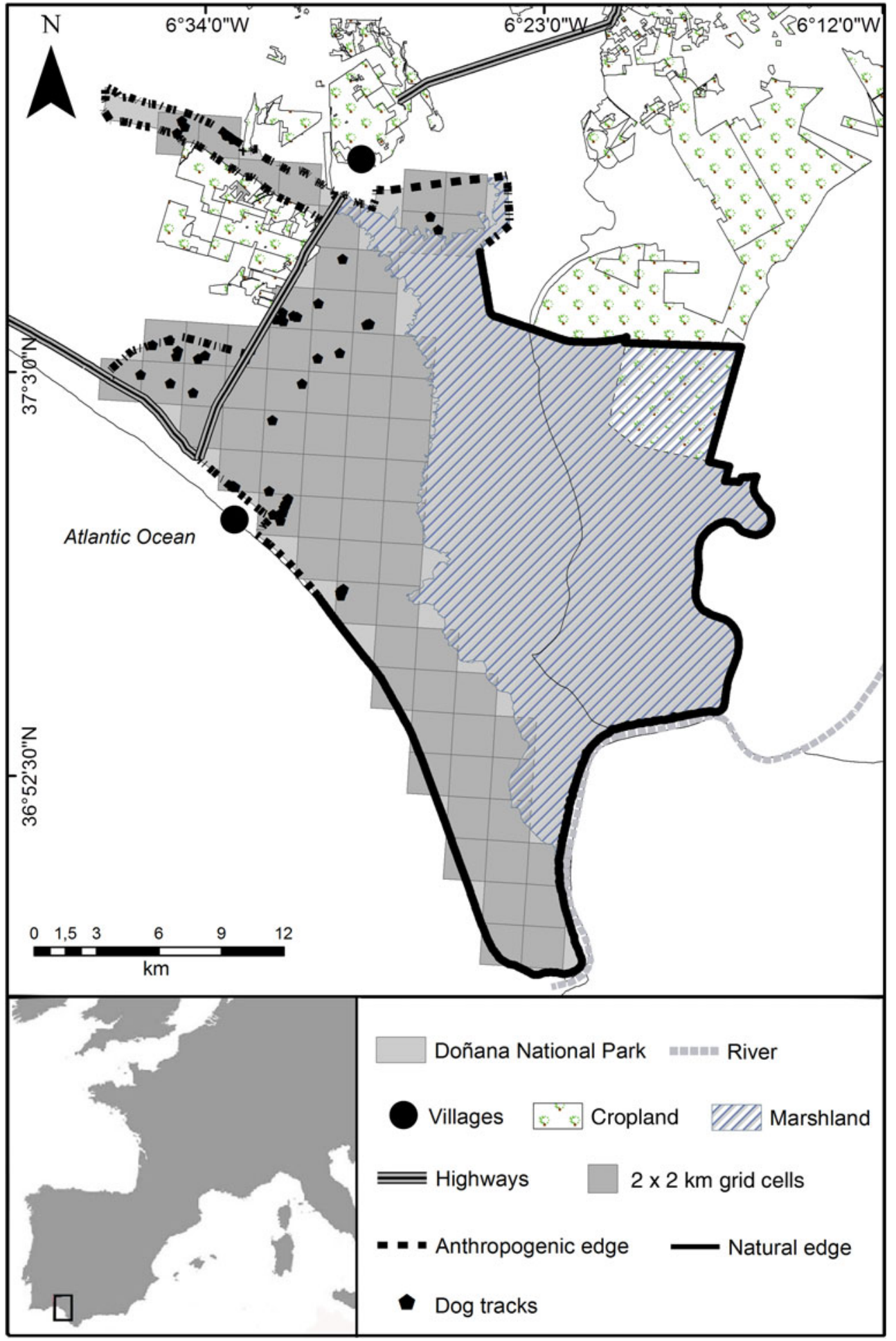

FIG. 1 Doñana National Park and the surrounding area. The locations where dog tracks were detected between November 2007 and April 2009 are shown. The rectangle on the inset indicates the location of the main map in southern Spain. close proximity to human settlements, crop fields and a highway, and the natural edges as the southern edge, along the Atlantic Ocean, and the eastern edge, along the Guadalquivir River (Fig. 1).

The suburban resort of Matalascañas, close to the western edge of the Park, has a fluctuating population between winter and summer, with c. 2,710 people in the summer. The village of El Rocío, situated close to the northern edge, has c. 1,635 residents year-round, although a spring pilgrimage brings up to one million visitors. There are also private farms nearby. The Park is fenced but the fence is permeable to small and medium-sized animals, including dogs.

The climate is Mediterranean sub-humid, with mild wet winters and hot dry summers, and mean annual rainfall of 
c. $550 \mathrm{~mm}$. The Park's three main biotopes are scrubland, dunes and marsh (Valverde, 1958). Scrubland accounts for approximately half of the Park's surface area and is mainly characterized by heterogeneous patches of xerophytic plant species such as Halimium sp. and Cistus sp., and hydrophytic species such as Erica sp., with some patches of Juniperus phoenica and Pistacia lentiscus shrubs. Interspersed among the scrublands are scattered cork oak trees Quercus suber, wild olive trees Olea europaea, and patches of pine Pinus pinea and eucalyptus Eucalyptus sp. plantations.

Larger mammals in the Park include wild boar Sus scrofa, red deer Cervus elaphus and fallow deer Dama dama. Wild carnivores include red fox Vulpes vulpes, Eurasian badger Meles meles, Egyptian mongoose Herpestes ichneumon, common genet Genetta genetta, least weasel Mustela nivalis, European polecat Mustela putorius, Eurasian otter Lutra lutra, wild cat Felis silvestris and Iberian lynx Lynx pardinus. As well as 14 small to medium-sized mammal species, 397 bird species have been recorded, approximately half of which are breeding in the Park.

\section{Methods}

\section{Surveys}

We carried out dog-track surveys on sandy paths in $692 \times 2$ $\mathrm{km}$ grid cells located across the scrubland and dune areas of the Park during the wet seasons of 2007-2008 and 20082009. Surveys were carried out at least 3 days after rainfall and each track detected was geo-referenced using a global positioning system.

We searched for dog tracks in each cell by walking at least $3 \mathrm{~km}$ along sandy roads and fire breaks.

We assessed the environmental suitability of sampling cells to sustain a feral dog population, based on potential prey availability and general habitat structure. Feral dogs are habitat generalists and opportunistic foragers (Marsack \& Greg, 1990; Boitani et al., 1995). Potential prey availability was estimated by counting tracks of small mammals, European rabbits Oryctolagus cuniculus, red-legged partridges Alectoris rufa, domestic cows Bos taurus and horses Equus caballus, and wild ungulates such as fallow deer, red deer and wild boar. Feral dogs hunt small prey and consume larger animals as carrion (Sillero-Zubiri \& Macdonald, 1997; Butler et al., 2004). We surveyed prey species by walking 7-10 $25 \mathrm{~m}$ transects of c. $1.7 \mathrm{~m}$ width and separated by at least $300 \mathrm{~m}$, within each $2 \times 2 \mathrm{~km}$ cell. In the first year transect surveys of prey species were carried out throughout the wet season, when tracks from dogs were surveyed, but in the second year all transect surveys of prey species were carried out in April to avoid possible inter-monthly variations in abundance of some species (Kufner, 1986; Palomares et al., 2001).
In the first year we recorded habitat structure in circles of $15 \mathrm{~m}$ radius around sampling points located every $300 \mathrm{~m}$ along the survey transects. We estimated visually the percentage of open ground cover and the percentage and modal height of three categories of vegetation: short shrubs (xerophytic species such as Halimium sp. and Cistus sp.), tall shrubs (Erica sp., J. phoenica and P. lentiscus), and trees. For each cell sampled we estimated the mean percentage cover at each sampling point.

\section{Data analysis}

We fitted generalized linear models with a binomial error distribution and a logit link function, in SAS v. 9.2 (SAS Institute, Cary, USA). We also incorporated methodological and climatic variables to control for their potential effects (Soto et al., 2010).

Each grid cell was associated with a set of habitat variables, such as vegetation type (dunes, $>60 \%$ of open ground cover; pine forest, $>60 \%$ of pine vegetation; Mediterranean shrub, $>60 \%$ of short or tall shrub vegetation), and prey abundance (abundance index of total prey per $\mathrm{km}$ ), and with a variable describing the location, based on the Euclidean distance from the centre of the cell to every infrastructure element; i.e. the fence close to human settlements (or anthropogenic edge of the Park), the fence without human settlements nearby (or natural edge of the Park), the nearest house or visitors' centre, and the nearest paved road.

We used a two-step approach to analyse data. Firstly, we assessed which methodological and climatic variables potentially affect the likelihood of detecting dogs' tracks and we selected the best-fitting model using an information-theoretic approach (Burnham \& Anderson, 2002). The models included the following variables: the observer who carried out the censuses, the relative humidity on census day (\%), the number of days since the last rain, the year, and the maximum temperature $\left({ }^{\circ} \mathrm{C}\right)$, calculated as the mean of the maximum temperature on the census day and the maximum temperature on two consecutive days before the census day. Climatic data were obtained from a meteorological station located inside the Park (Doñana Biological Station, 2009).

Secondly, we used this best-fitting model as a null model to develop a set of a priori models of detectability of dog tracks in the Park, based on three groups of hypotheses in relation to (1) the correlation between human presence and the presence of dog tracks (i.e. dogs being domestic), (2) dogs coming from a feral population (i.e. presence of dog tracks being related to environmental and/or prey variables), and (3) a combination of domestic and feral dogs. The variables included in the models were the minimum distance to the nearest house or visitors' centre, the 
minimum distance to a human settlement, the distance to the nearest paved road, the distance to the anthropogenic edge of the Park, the distance to the natural edge of the Park, the abundance index of total prey per $\mathrm{km}$, and the vegetation category. Among highly correlated variables ( $\tau>0.4$ ), explored using Kendall's $\tau$ statistics, we retained the distance to the anthropogenic edge of the Park as the variable that best summarized the human influence.

We used the Akaike Information Criterion corrected for a small sample size $\left(\mathrm{AIC}_{\mathrm{c}}\right)$ and calculated the difference in $\mathrm{AIC}_{\mathrm{c}}$ between each model and the model with the lowest $\mathrm{AIC}_{\mathrm{c}}\left(\Delta \mathrm{AIC}_{\mathrm{c}}\right.$; Burnham \& Anderson, 2002). The model with the lowest $\mathrm{AIC}_{\mathrm{c}}$ and those with $\Delta \mathrm{AIC}_{\mathrm{c}} \leq 2$ were considered to be supported. $\triangle \mathrm{AICc}$ values were used to compute Akaike weights $\left(\omega_{i}\right.$; Burnham \& Anderson, 2002). In addition, the relative importance of the predictor variable $j\left(\omega_{j}\right)$ was determined as the sum of $\omega_{i}$ across all models where $j$ occurred. Larger $\omega_{j}$ values indicated a higher relative importance of variable $j$ compared to other variables. For each hypothesis we used data from both years and we began by fitting all variables and then successively removed the terms that decreased the AIC most (Crawley, 2002).

Finally, we explored the classification accuracy of the selected models, using the nonparametric estimate of the area under the curve (AUC) of receiver operating characteristic plots (Hosmer \& Lemeshow, 2000). AUC indices are in the range $0.5-1$, with $0.5-0.7$ indicating poor discrimination, 0.7-0.8 acceptable discrimination, $0.8-0.9$ good discrimination, and $>0.9$ outstanding discrimination. The area under the receiver operating characteristic curve is often used as a single threshold-independent measure for model performance and tests the ability of the model to discriminate between grid cells where dog tracks are present and those where tracks are absent (Fielding \& Bell, 1997).

\section{Results}

Our surveys covered a total of $471 \mathrm{~km}$ and we recorded 72 observations of dog tracks (Fig. 1). We detected dog tracks in 16 grid cells in 2007-2008 and in 12 grid cells in 20082009.

We found a strong correlation between distance to the anthropogenic edge of the Park, distance to the natural edge of the Park, distance to the nearest village, and distance to the nearest paved road. Analyses were focused on the first two.

The best-fitting model explaining detection of dog tracks, based on non-biological factors, included humidity as a positive but non-significant predictor (odds ratio $=1.035$, $\chi^{2}=2.159, P=0.142$ ) and the number of days since the last rain as a negative and significant variable correlated with detection of $\operatorname{dog}$ tracks (odds ratio $=0.931, \chi^{2}=4.286$,
$\mathrm{P}=0.035$ ). Both predictors were therefore included as covariables in further analyses.

The analysis of detectability of dog tracks based on human-related, habitat and prey variables showed that the a priori hypothesis best adjusted to data included only human-related predictors. The best model for describing the detection of dog tracks in the Park, after adjusting for detection probability variables in the null model, included the distance to the anthropogenic edge of the Park (accounting for $27.6 \%$ of the deviance). The next model included the distance to the anthropogenic edge and the distance to the natural edge of the Park (models 1 and 3; Table 1). Detection of dogs was significantly and negatively associated with the distance to the anthropogenic edge of the Park (odds ratio = $0.737, \chi^{2}=8.020, P=0.005$; Fig. 2 ). The equation for this model (model 1; Table 1) is

$$
\begin{aligned}
\operatorname{logit}(\mathrm{P})= & (-3.32 \pm \mathrm{SE} 1.86)-(0.31 \pm \mathrm{SE} 0.11) D \_A N T \\
& +(0.05 \pm \mathrm{SE} 0.02) \text { Hum } \\
& -(0.06 \pm \mathrm{SE} 0.04) \text { Rain }
\end{aligned}
$$

where $\mathrm{P}$ is the probability of dog occurrence, $D \_A N T$ is the distance to the anthropogenic edge of the Park, Hum is humidity, and Rain is the number of days since the last rain. The relative importance of $D \_A N T$ was $\omega_{j}=0.999$. The discriminating ability of the top model was AUC $=0.802(P<0.0001)$.

\section{Discussion}

The detection of dog tracks in the Park was associated with distance from the anthropogenic boundary, a synthetic indicator of human influence that captures the effects of distance to the nearest village and the nearest paved road. We found many signs of dogs near the borders of the Park closer to households and we were unable to detect signs of dogs far from these anthropogenic edges. The detectability of dog tracks did not seem to be related to environmental variability such as vegetation type or prey availability. These findings support our hypothesis that dogs within the Park are domestic dogs that arrive occasionally from the surrounding matrix, not feral dogs living and reproducing freely. The lack of association between detection of dog tracks and availability of wild food resources suggests that dogs are dependent on humans for provision of food (Butler et al., 2004; Vanak, 2008; Vanak \& Gompper, 2009b).

Although feral dogs survive and reproduce independently of human assistance, some feed on waste food discarded by humans (Green \& Gipson, 1994). Hence, a population of feral dogs within the Park could subsidize their diet in human settlements bordering the Park. Nevertheless, as the degree of reliance on humans distinguishes feral from domestic dogs, if dogs using the Park 
TABLE 1 Logistic regression models used to investigate the effects of anthropogenic, habitat and a combination of all variables on detection of dog tracks at Doñana National Park (Fig. 1), with the model deviance, the sample-size-adjusted Akaike's information criterion $\left(\mathrm{AIC}_{\mathrm{c}}\right)$, the difference in $\mathrm{AIC}_{\mathrm{c}}$ value relative to the model with the lowest $\mathrm{AIC}_{\mathrm{c}}\left(\triangle \mathrm{AIC}_{\mathrm{c}}\right)$, and the $\mathrm{AIC}_{\mathrm{c}}$ weight.

\begin{tabular}{lcccc}
\hline & & & & $\mathrm{AIC}_{\mathrm{c}}$ \\
Model code & Deviance & $\mathrm{AIC}_{\mathrm{c}}$ & $\Delta \mathrm{AIC}_{\mathrm{c}}$ & weight \\
\hline $\begin{array}{l}\text { Null model } \\
\text { Anthropogenic }\end{array}$ & 139.210 & 121.107 & 12.939 & 0.000 \\
$\begin{array}{l}\text { D_ANT, Hum, Rain } \\
\text { D_NAT, D_ANT, }\end{array}$ & 100.170 & 108.168 & 0.000 & 0.276 \\
D_HOU, Hum, Rain & 97.470 & 109.469 & 1.301 & 0.144 \\
D_NAT, D_ANT,Hum, & 98.240 & 108.242 & 0.074 & 0.266 \\
Rain & & & & \\
D_ANT, D_HOU, & 99.750 & 109.747 & 1.579 & 0.125 \\
Hum, Rain & & & & \\
Habitat & & & & \\
Pt,Hum, Rain & 112.970 & 120.971 & 12.803 & 0.000 \\
Veg,Hum, Rain & 106.720 & 122.265 & 14.097 & 0.000 \\
Pt,Veg,Hum, Rain & 110.900 & 122.897 & 14.729 & 0.000 \\
Global & & & & \\
D_NAT, D_ANT, & 97.950 & 111.953 & 3.785 & 0.042 \\
D_HOU,Pt,Hum, Rain & & & & \\
D_NAT, D_ANT, Pt, & 98.850 & 110.853 & 2.685 & 0.072 \\
Hum, Rain & & & & \\
D_ANT, Pt,Hum, Rain & 100.810 & 110.811 & 2.643 & 0.074 \\
\hline
\end{tabular}

${ }^{*} D \_A N T$, distance to the anthropogenic edge of the Park; Hum, relative humidity; Rain, number of days since last rain; D_NAT, distance to the natural edge of the Park; $D \_H O U$, distance to the nearest house or visitors' centre; $P t$, abundance index of total prey per $\mathrm{km}$; Veg, vegetation category

were from a feral population, living and reproducing freely but accessing human subsidies for food, we would expect dog detectability to be dependent on habitat suitability and/or the availability of wild food, and marginally dependent on human-related variables. Compared to domestic dogs, feral dogs are highly social, usually living in packs or groups (Daniels \& Bekoff, 1989; Green \& Gipson, 1994), and we only detected isolated dog tracks. Camera-trapping studies conducted during the same period within the Park only detected dogs near human settlements, and all animals were identified as domestic based on their physical appearance (authors, pers. obs.).

The higher occurrence of dog tracks at the edges of the Park supports the idea that the presence of domestic dogs may be exacerbating the anthropogenic edge effect. Other authors have also reported a higher occurrence of domestic dogs near the edges of natural reserves compared to their interiors (Butler et al., 2004; Srbek-Araujo \& Chiarello, 2008; Lacerda et al., 2009; Marks \& Duncan, 2009). Domestic dogs could therefore be considered a human-derived edge effect in protected areas, and wildlife may be most at risk of predation and displacement by dogs near the anthropogenic border. The higher occurrence of dogs in these border

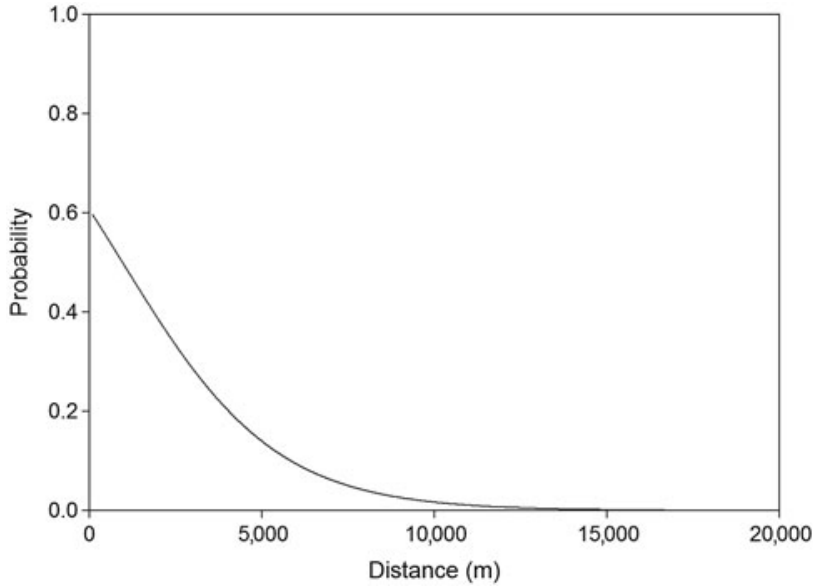

Fig. 2 Probability of detection of dog tracks as a function of distance to the anthropogenic edge of Doñana National Park (Fig. 1) during the wet seasons of 2007-2008 and 2008-2009.

areas may exacerbate the existing edge effects on key population parameters (Murcia, 1995; Noss \& Csuti, 1997), which cause the peripheries of reserves to function as population sinks (Woodroffe \& Ginsberg, 1998; Revilla et al., 2001).

Virulent, multi-host pathogens transmitted from dogs can cause mortality in wild animals and exacerbate the direct edge effects caused by domestic dogs in protected areas (Woodroffe \& Ginsberg, 1999; Cleaveland et al., 2000).

This represents a complicated scenario for conservationists, especially in areas with threatened endemic carnivore populations or where reserve size is small relative to species' home ranges. More research is needed to help prevent or diminish the effects of domestic dogs on native fauna in protected areas. Transborder management actions must be prioritized in protected areas and we suggest that measures should include constraining the free-roaming of domestic dogs, raising awareness of responsible dog-ownership and biodiversity conservation (as some studies have indicated that dog interactions with prey species may be driven by hunger and inadequate diet; Sepúlveda et al., 2014), removing un-owned dogs from reserve boundaries near human settlements, strengthening pet policies by forbidding unleashed dogs in public facilities, and imposing sanctions on owners whose dogs roam freely inside protected areas.

In the specific case of Doñana National Park, dogs living or spending time inside the protected area may pose a serious risk for the Iberian lynx (Ferreras et al., 1992; Meli et al., 2009; Millán et al., 2009), the most threatened felid species (Nowell \& Jackson, 1996). Hence, controlling the dog population at the Park is required for the conservation of one of the last meta-populations of the species. Free-roaming dogs are now prohibited from visitor facilities in the surroundings of the Park and, in light of the findings of this study, the Park's authorities are considering strengthening pet policies and developing campaigns of local awareness. 


\section{Acknowledgements}

This study was financed by the projects CGL2004-00346/ BOS (Spanish Ministry of Education and Science) and 17/ 2005 (Spanish Ministry of the Environment; National Parks Research Programme), and sponsored by LandRover España S.A. CS received a JAE pre-doctoral grant from CSIC (Spanish National Research Council). We are thankful to J.C. Rivilla and S. Desniça for their assistance during fieldwork, to N. Fernández for his help with data analysis, and to C. Dickman and P. Ferreras for their comments.

\section{References}

Banks, P. \& Bryant, J. (2007) Four-legged friend or foe? Dog walking displaces native birds. Biology Letters, 3, 611-613.

Boitani, L., Francisci, F., Ciucci, P. \& Andreoli, G. (1995) Population biology and ecology of feral dogs in central Italy. In The Domestic Dog. Its Evolution, Behaviour, and Interactions with People (ed. J. Serpell), pp. 217-244. Cambridge University Press, Cambridge, UK.

Burnham, K.P. \& Anderson, D.R. (2002) Model Selection and Multimodel Inference. A Practical Information-Theoretic Approach, 2nd edition. Springer, New York, USA.

Butler, J.R.A. \& DU Toit, J.T. (2002) Diet of free-ranging domestic dogs (Canis familiaris) in rural Zimbabwe: implications for wild scavengers on the periphery of wildlife reserves. Animal Conservation, 5, 29-37.

Butler, J.R.A., DU Toit, J.T. \& Bingham, J. (2004) Free-ranging domestic dogs (Canis familiaris) as predators and prey in rural Zimbabwe: threats of competition and disease to large wild carnivores. Biological Conservation, 115, 369-378.

Cleaveland, S., Appel, M.G.J., Chalmers, W.S.K., Chillingworth, C., KaAre, M. \& Dye, C. (2000) Serological and demographic evidence for domestic dogs as a source of canine distemper virus infection for Serengeti wildlife. Veterinary Microbiology, 72, 217-227.

Crawley, M.J. (2002) Statistical Computing: An Introduction to Data Analysis Using S-Plus. John Wiley \& Sons Ltd, Chichester, UK.

Daniels, T.J. \& BekofF, M. (1989) Spatial and temporal resource use by feral and abandoned dogs. Ethology, 181, 300-312.

Doñana Biological Station (2009) ICTS de la Reserva Biológica de Doñana. Http://icts.ebd.csic.es [accessed September 2009].

Ferreras, P., Aldama, J.J., Beltrán, J.F. \& Delibes, M. (1992) Rates and causes of mortality in a fragmented population of lberian lynx Felis pardina Temminck, 1824. Biological Conservation, 61, 197-202.

Fielding, A.H. \& Bell, J.F. (1997) A review of methods for the assessment of prediction errors in conservation presence/absence models. Environmental Conservation, 24, 38-49.

Fiorello, C.V., Noss, A.J. \& Deem, S.L. (2006) Demography, hunting ecology, and pathogen exposure of domestic dogs in the Isoso of Bolivia. Conservation Biology, 20, 762-771.

Glen, A.S. \& DickMan, C.R. (2005) Complex interactions among mammalian carnivores in Australia, and their implications for wildlife management. Biological Reviews, 80, 387-401.

Green, J.S. \& Gipson, P.S. (1994) Feral dogs. In The Handbook: Prevention and Control of Wildlife Damage (eds S.E. Hygnstrom, R.M. Timm \& G.E. Larson), pp. 1-7. University of Nebraska, Lincoln, USA.
Hosmer, D.W. \& Lemeshow, S. (2000) Applied Logistic Regression, and edition. Wiley, Inc., New York, USA.

IUCN (2012) IUCN Red List of Threatened Species v. 2012.1. Http:// www.iucnredlist.org [accessed 25 June 2012].

KRUUK, H. \& S Nell, H. (1981) Prey selection by feral dogs from a population of marine iguanas Amblyrhynchus cristatus. Journal of Applied Ecology, 18, 197-204.

KufNer, M.B. (1986) Tamaño actividad, densidad relativa y preferencias de hábitat de los pequeños y medianos mamíferos de Doñana, como factores condicionantes de su tasa de predación. $\mathrm{PhD}$ thesis. Universidad Autónoma, Madrid, Spain.

Lacerda, A.C.R., Tomas, W.M. \& Marinho-Filho, J. (2009) Domestic dogs as an edge effect in the Brasília National Park, Brazil: interactions with native mammals. Animal Conservation, 12, 477487.

MANOR, R. \& SALTZ, D. (2004) The impact of free-ranging dogs on gazelle kid/female ratio in a fragmented area. Biological Conservation, 119, 231-236.

Marks, B.K. \& Duncan, R.S. (2009) Use of forest edges by free-ranging cats and dogs in an urban forest fragment. Southern Nature, 8, 427-436.

Marsack, P. \& Greg, C. (1990) Feeding behavior and diet of dingoes in the Nullarbor region, Western Australia. Australian Wildlife Research, 17, 349-357.

Meli, M.L., Cattoril, V., Martínez, F., López, G., Vargas, A., Simón, M.A. et al. (2009) Feline leukaemia virus and other pathogens as important threats to the survival of the Critically Endangered Iberian lynx (Lynx pardinus). PLoS ONE, 4, e4744.

Millán, J., Candela, M.G., Palomares, F., Cubero, M.J., Rodriguez, A., Barral, M. et al. (2009) Disease threats to the endangered Iberian lynx (Lynx pardinus). Veterinary Journal, 182, 114-124.

Mitchell, B.D. \& Banks, P.B. (2005) Do wild dogs exclude foxes? Evidence for competition from dietary and spatial overlaps. Australian Ecology, 30, 581-591.

Murcia, C. (1995) Edge effects in fragmented forests: implications for conservation. Trends in Ecology and Evolution, 10, 58-62.

Nesbitt, W.H. (1975) Ecology of a feral dog pack on a wildlife refuge. In The Wild Canids (ed. M.W. Fox), pp. 391-395. Van Nostrand Reinhold Company, New York, USA.

Noss, R.F. \& Csuti, B. (1997) Habitat fragmentation. In Principles of Conservation Biology (eds G.K. Meffe \& C. R. Carroll), pp. 269-304. Sinauer Associates, Inc., Sunderland, USA.

Nowell, K. \& JACKsOn, P. (1996) Wild Cats: Status Survey and Conservation Action Plan. IUCN/SSC, Gland, Switzerland.

Odell, E.A. \& Knight, R.L. (2001) Songbird and medium-sized mammal communities associated with exurban development in Pitkin County, Colorado. Conservation Biology, 15, 1143-1150.

Ordeñana, M.A., Crooks, K.R., Boydston, E.E., Fisher, R.N., Lyren, L.M., SiUdyla, S. et al. (2010) Effects of urbanization on carnivore species distribution and richness. Journal of Mammalogy, 91, 1322-1331.

Palomares, F., Delibes, M., Revilla, E., Calzada, J. \& Fedriani, J.M. (2001) Spatial ecology of Iberian lynx and abundance of European rabbits in southwestern Spain. Wildlife Monographs, 148, $1-36$.

Revilla, E., Palomares, F. \& Delibes, M. (2001) Edge-core effects and the effectiveness of traditional reserves in conservation: Eurasian badgers in Doñana National Park. Conservation Biology, $15,148-158$.

Sepúlveda, M.A., Singer, R.S., Silva-Rodríguez, E., Stowhas, P. \& Pelican, K. (2014) Domestic dogs in rural communities around protected areas: conservation problem or conflict solution? PLoS ONE, 9(1), e86152. 
Sillero-Zubiri, C. \& Macdonald, D.W. (1997) The Ethiopian Wolf: Status Survey and Conservation Action Plan. IUCN Canid Specialist Group, Gland, Switzerland, and Cambridge, UK.

Soto, C.A., Desnica, S. \& Palomares, F. (2010) Non-biological factors affecting track censuses; implications for sampling design and reliability. European Journal of Wildlife Research, 58, 117-126.

Srbek-Araujo, A.C. \& Chiarello, A.G. (2008) Domestic dogs in Atlantic forest preserves of south-eastern Brazil: a camera-trapping study on patterns of entrance and site occupancy rates. Brazilian Journal of Biology, 68, 771-779.

Torres, P.C. \& Prado, P.I. (2010) Domestic dogs in a fragmented landscape in the Brazilian Atlantic Forest: abundance, habitat use and caring by owners. Brazilian Journal of Biology, 70, 987-994.

Valverde, J.A. (1958) An ecological sketch of the Coto Doñana. British Birds, 51, 1-23.

VANAK, A.T. (2008) Intraguild interactions between native and domestic carnivores in central India. $\mathrm{PhD}$ thesis. University of Missouri, Columbia, USA.

VAnak, A.T. \& Gompper, M.E. (2009a) Dogs Canis familiaris as carnivores: their role and function in intraguild competition. Mammal Review, 39, 265-283.

VANAK, A.T. \& Gompper, M.E. (2009b) Dietary niche separation between sympatric free-ranging domestic dogs and Indian foxes in central India. Journal of Mammalogy, 90, 1058-1065.

Vanak, A.T., Thaker, M. \& Gompper, M.E. (2009) Experimental examination of behavioural interactions between free-ranging wild and domestic canids. Behavioral Ecology and Sociobiology, 64, 279287.

Woodroffe, R. \& Ginsberg, J.R. (1998) Edge effects and the extinction of populations inside protected areas. Science, 280, 21262128.

Woodroffe, R. \& Ginsberg, J.R. (1999) Conserving the African wild dog Lycaon pictus. I. Diagnosing and treating causes of decline. Oryx, 33, 132-142.

\section{Biographical sketches}

CAROLINA SOTо is broadly interested in exploring how species select their habitats according to different ecological traits and inter-specific interactions between species in the same guild, and how that knowledge can be used to improve the management of populations of conservation concern. She aims to connect scientific research to decision tools and effective conservation management. She is also keen to research how evidence is used in conservation practice and evaluate the effectiveness of management plans for conservation of threatened species of mammalian carnivores. FRANCISCO PALOMARES focuses on ecology, inter-specific interactions, predator-prey relationships and conservation of mammalian carnivores. In recent years he has mainly been researching large American felids, developing effective monitoring techniques using non-invasive methods and studying the patterns of coexistence between big cats. 